CENTRE FOR ECONOMIC PERFORMANCE

DISCUSSION PAPER NO. 349

\title{
EUROPEAN VERSUS US UNEMPLOYMENT: DIFFERENT RESPONSES TO INCREASED DEMAND FOR SKILL?
}

June 1997

R.JACKMAN, R.LAYARD, M.MANACORDA and B.PETRONGOLO 


\section{ABSTRACT}

According to Paul Krugman, "the European unemployment problem and the US inequality problem are two sides of the same coin". In other words, both continents have had the same shift in demand towards skill; in the US relative wages have adjusted and in Europe not.

The implication of this hypothesis is that in Europe the unemployment rate for the unskilled will have risen but the unemployment rate for the skilled will have fallen. In fact it has risen.

To investigate the hypothesis more systematically we develop an internally consistent model which allocates the change in a country's unemployment between that resulting from (a) shifts in relative demand for skill minus shifts in relative supply, (b) shifts in the relative intercepts of skilled and unskilled wage functions, (c) shifts in aggregate wage pressure. We show that the rise in British unemployment relative to the US since the 1970s is almost certainly due to shifts in aggregate wage pressure. Similarly for 5 other European countries the combination of (a) and (b) accounts for none of the increase in unemployment since the 1970s.

The paper was produced as part of the Centre's 
Human Resources Programme 
EUROPEAN VERSUS US UNEMPLOYMENT: DIFFERENT RESPONSES TO INCREASED DEMAND FOR SKILL?

R. Jackman, R. Layard, M. Manacorda and B. Petrongolo 
Published by

Centre for Economic Performance

London School of Economics and Political Science

Houghton Street

London

WC2A 2AE

CR. Jackman, R. Layard, M. Manacorda and B. Petrongolo, 1997

ISBN 0853283966 


\section{EUROPEAN VERSUS US UNEMPLOYMENT: DIFFERENT RESPONSES TO INCREASED DEMAND FOR SKILL?}

R. Jackman, R. Layard, M. Manacorda and B. Petrongolo

Page

1. The Framework of Analysis 2

Skill-specific unemployment 2

Aggregate unemployment 5

$\begin{array}{ll}\text { Mismatch } & 7\end{array}$

2. Evidence on Europe and the US 9

Production function 9

Wage functions 9

Changes in unemployment. Britain versus the US10 Increased mismatch? Europe versus the US 12

3. Conclusions 14

Endnotes $\quad 16$

Annex 1 Deriving equation (5) 18

Annex 2 Basic data 21

Annex 3 Adjustment for "quality" 24

Tables 26

Figure $\quad 30$

References $\quad 31$

The Centre for Economic Performance is financed by the Economic and Social Research Council. 


\section{ACKNOWLEDGEMENTS}

Richard Layard is the Director of the Centre for Economic Performance. Richard Jackman is Director of the Human Resources programme at the Centre and Marco Manacorda and Barbara Petrongolo are research assistants for the programme. Financial support from the Economic and Social Research Council is gratefully acknowledged. 


\section{EUROPEAN VERSUS US UNEMPLOYMENT: DIFFERENT RESPONSES TO INCREASED DEMAND FOR SKILL?}

\section{R. Jackman, R. Layard, M. Manacorda and B. Petrongolo}

According to Paul Krugman, "the European unemployment problem and the US inequality problem are two sides of the same coin" (Krugman, 1994). ${ }^{1}$ This is now the conventional wisdom. According to this view, there has been a universal shift in the demand for labour in favour of those with more skill, but countries differ in their wage flexibility. In the US which has flexible wages, relative wages have adjusted; in Europe, which has inflexible wages, the impact has been on relative employment rates. In consequence, unemployment in the US has not risen since the 1970s, while in Europe it has soared.

Is this really the reason why European unemployment has risen? Obviously it could be. But in fact there is no evidence that it is. For example one implication of the Krugman hypothesis is that, when relative wages are rigid, the shift in demand should lead to a rise in unskilled unemployment but a fall in the unemployment of skilled workers. But one of the most striking facts about Europe is that skilled unemployment rose as much as unskilled unemployment (in proportional terms). In fact it is only in the US that there is a clear upward trend in unskilled relative to skilled unemployment. So there is a lot to be cleared up.

The purpose of this paper is to develop and apply a framework for explaining the movement of skilled and unskilled unemployment rates and thus of the total unemployment rate. We first develop in Section 1 a model of skill-specific unemployment, which involves a demand function and a wage-response function, with supply treated as exogenous. From this we derive a framework for decomposing changes in aggregate unemployment, so as to isolate the effects of differential shifts in the relative demand and supply of skill. This then enables us to show how far changes in unemployment were due to increases in "skills mismatch". 
In Section 2 we apply this framework in detail to the changes in skill-specific unemployment in Britain and the US. We then extend the analysis to cover most of the main European countries as well, using a more short-cut framework of analysis. Section 3 summarises our conclusions.

\section{THE FRAMEWORK OF ANALYSIS}

\section{Skill-specific unemployment}

We begin by analysing skill-specific unemployment. We concentrate on a binary division between two groups, skilled (group 1) and unskilled (group 2), though the approach can be generalised.

The demand side comes from a Cobb-Douglas production function, which we show later is supported by the evidence. Thus

$$
Y^{\prime} A N_{1}^{\mathrm{a}} N_{2}^{1 \& \mathrm{a}}
$$

where $\mathrm{Y}$ is output and $\mathrm{N}_{\mathrm{i}}$ is employment. Thus we can immediately see the dilemma motivating the Krugman analysis. For

$$
\frac{N_{1} / L_{1}}{N_{2} / L_{2}}, \frac{W_{2}}{W_{1}}\left(\frac{\mathrm{a}}{1 \& \mathrm{a}} / \frac{L_{1}}{L_{2}}\right), \frac{W_{2}}{W_{1}} B
$$

where $\mathrm{B}$ denotes the term in brackets. Changes in B reflect shifts in the demand for skill relative to its supply. Over time a rises relentlessly, and if $\mathrm{L}_{1}$ does not rise enough $\mathrm{B}$ rises. This must then lead to either widening inequality of wages $\left(\mathrm{W}_{2} / \mathrm{W}_{1}\right.$ down $)$ or falls in the relative employment rate of the unskilled $\left(\mathrm{N}_{2} / \mathrm{L}_{2}\right.$ down relative to $\left.\mathrm{N}_{1} / \mathrm{L}_{1}\right)$ - or both.

But to gain any serious insight into what is happening, we must focus first on the separate market for each type of skill. For skilled labour, demand is given by 


$$
\left.\log W_{1}{ }^{\prime} \log A \% \operatorname{dog} \mathrm{a} \% \mathrm{a} \& 1\right) \log \frac{N_{1}}{N_{2}}
$$

where $\mathrm{W}_{1}$ is the real wage. Differentiating and then adding and subtracting (1-a)d $\log \left(\mathrm{L}_{1} / \mathrm{L}_{2}\right)$ gives $^{2}$

$$
\begin{gathered}
d \log W_{1}{ }^{\prime} d \log A \% \operatorname{dog} \frac{N_{1}}{N_{2}} d \mathrm{a} \&(1 \& \mathbf{a}) d \log \frac{N_{1} / L_{1}}{N_{2} / L_{2}} \% d \log \mathrm{a} \&(1 \& \mathbf{a}) d \log \frac{L_{1}}{L_{2}} \\
' d \log A \% \operatorname{dog} \frac{N_{1}}{N_{2}} d \mathrm{a} \%(1 \& \mathbf{a}) d \log \frac{1 \& u_{2}}{1 \& u_{1}} \%(1 \& \mathbf{a}) d \log B
\end{gathered}
$$

At the same time skilled wages respond to skilled employment according to the double-log wage formation relationship ${ }^{3}$

$$
\log W_{1}^{\prime} z_{1} \& ? \log u_{1}
$$

or

$$
d \log W_{1}^{\prime} d z_{1} \& ? d \log u_{1}
$$

Combining (1) and (2) gives

$$
\begin{gathered}
d u_{1}{ }^{\prime} \quad \& \mathrm{f}_{1}(1 \& \mathrm{a}) d \log B \% \mathrm{f}_{1}\left(d z_{1} \& d \log A \& \log \frac{N_{1}}{N_{2}} d \mathrm{a}\right) \\
\%_{1}(1 \& \mathrm{a})\left(1 \& u_{2}\right)^{\& 1} d u_{2}
\end{gathered}
$$

where $\mathrm{f}_{1}{ }^{\prime} u_{1} /\left(? \%(1 \& \mathrm{a}) u_{1} /\left(1 \& u_{1}\right)\right)$. By analogy 


$$
\begin{gathered}
d u_{2}{ }^{\prime} \mathrm{f}_{2} \mathrm{a} d \log B \% \mathrm{f}_{2}\left(d z_{2} \& d \log A \& \log \frac{N_{1}}{N_{2}} d \mathrm{a}\right) \\
\% \mathbb{f}_{2} \mathrm{a}\left(1 \& u_{1}\right)^{\& 1} d u_{1}
\end{gathered}
$$

where $\mathrm{f}_{2}{ }^{\prime} u_{2} /\left(? \% u_{2} /\left(1 \& u_{2}\right)\right)$.

One key lesson emerges at once from (3) and (4) taken together. The unemployment rates of both groups will be constant, with $\mathrm{du}_{1}=\mathrm{du}_{2}=0$, if

(i) there is no change in B - the balance between relative demand and relative supply, and

(ii) the wage functions of each group move up by an amount equal to $d \log A \% \operatorname{dog}\left(N_{1} / N_{2}\right) d \mathrm{a}$.

If however B changes, the unemployment rates will shift, unless the wage functions adjust appropriately so as to offset this effect.

Going on, it is illuminating to divide the second (bracketed) term in each equation into two parts, one reflecting shifts in the average wage function and the other shifts in the relative wage function. If $d \bar{z}^{\prime}$ a $\left.d z_{1} \% 1 \& \mathrm{a}\right) d z_{2}$ we can write

$$
\begin{gathered}
d z_{i} \& d \log A \& \log \frac{N_{1}}{N_{2}} d \mathrm{a}^{\prime}\left(d z_{i} \& d \bar{z}\right) \%\left(d \bar{z} \& d \log A \& \log \frac{N_{1}}{N_{2}} d \mathrm{a}\right) \\
{ }^{\prime}\left(d z_{i} \& d \bar{z}\right) \% d A W P
\end{gathered}
$$


Here AWP refers to aggregate wage pressure, while $\left(\mathrm{dz}_{1}-\mathrm{d} Q\right)$ and $\left(\mathrm{dz}_{2^{-}}\right.$ dQ) reflect shifts in the relative wage function: if one is positive, the other is negative.

If we insert these changes into (3) and (4), we can get some real insight into what is going on. We have

$$
\begin{gathered}
d u_{1}{ }^{\prime} \& \mathrm{f}_{1}(1 \& \mathrm{a}) d \log B \%_{1}\left(d z_{1} \& d \bar{z}\right) \%_{1}(d A W P) \\
\% \mathbb{f}_{1}(1 \& \mathrm{a})\left(1 \& u_{2}\right)^{\& 1} d u_{2} \\
d u_{2}{ }^{\prime} \mathrm{f}_{2} \mathrm{a} d \log B \% \mathbb{f}_{2}\left(d z_{2} \& d \bar{z}\right) \%_{2}(d A W P) \%_{2} \mathrm{a}\left(1 \& u_{1}\right)^{\& 1} d u_{1}
\end{gathered}
$$

We can now see how the relative wage functions have to shift if B changes, in order to prevent unemployment changing. Thus we can restate more generally the conditions for constant unemployment rates $\left(\mathrm{du}_{1}, \mathrm{du}_{2}=0\right)$. The rates are constant if

(i) $d z_{1} \& d \bar{z}^{\prime}(1 \& \mathrm{a}) d \log B$, which also implies $d z_{2} \& d \bar{z}^{\prime} \& \mathrm{a} d \log B$, and (ii) $d A W P^{\prime} d \bar{z} \& d \log A \& \log \left(N_{1} / N_{2}\right) d \mathrm{a}^{\prime} 0$.

The wage functions must shift to offset the change in imbalance, and there must be no change in aggregate wage pressure.

\section{Aggregate unemployment}

We can now look at the change in aggregate unemployment, du. To get this, we solve (3') and (4') to get the reduced form equations for $\mathrm{du}_{1}$ and $\mathrm{du}_{2}$ and then take a weighted average, allowing also for the compositional shift. Thus the change, du, includes a compositional effect, as well as effects from $\mathrm{d} \log \mathrm{B},\left(\mathrm{dz}_{1}-\mathrm{dQ}\right),\left(\mathrm{dz}_{2}-\mathrm{dQ}\right)$, and $\mathrm{d}$ AWP:

$$
d u^{\prime} ?{ }_{1} d \log B
$$

(imbalance shock) 


$$
\begin{array}{l|l}
\begin{array}{l}
\%_{2}\left(d z_{1} \& d \bar{z}\right) \\
\%_{3}\left(d z_{2} \& d \bar{z}\right) \\
\%_{4} d A W P
\end{array} & \left.\% u_{1} \& u_{2}\right) d\left(L_{1} / L\right) \\
\text { (relative wage shock) } \\
\text { (aggregate wage shock) } \\
\text { (compositional effect) }
\end{array}
$$

where the $?_{\mathrm{i}} \mathrm{s}$ are defined in Annex 1. There are analogous equations which determine $\mathrm{du}_{1}$ and $\mathrm{du}_{2}$, also shown in Annex 1. In our empirical analysis we therefore show the breakdown of $\mathrm{du}, \mathrm{du}_{1}$ and $\mathrm{du}_{2}$ for both Britain and the US into the categories identified in equation (5).

This seems a reasonable breakdown. If unemployment rates change and there has been no altered balance between relative demand and supply, then in the most general sense the change in unemployment must result from changes in wage behaviour at given unemployment rates. The changes in wage behaviour will in turn reflect all kinds of changes - in unemployment benefits, wage bargaining behaviour, taxes, import prices and so on. But if our focus is on the issue of skills imbalance, it is natural to group all the other issues together under the heading of wage pressure.

But are our definitions of "neutrality" appropriate with respect to either imbalance or wage pressure?

(i) We define a neutral shift in demand and supply as one in which there is no change in $\frac{\mathrm{a}}{1 \& \mathrm{a}} / \frac{L_{1}}{L_{2}}$, and

(ii) We define a neutral change in wage behaviour as one where the wage function shifts by $d \log A+\log \left(N_{1} / N_{2}\right)$ da.

The first point is that if we redefined one of these criteria of neutrality, we should have to redefine the other, in order to ensure that there was no effect on unemployment if both changes were neutral. But how reasonable is each definition, taken on its own? 
(i) A neutral shift in demand and supply. For neutrality we require

$$
d \log \frac{\mathrm{a}}{1 \& \mathrm{a}} \& d \log \frac{L_{1} / L}{L_{2} / L}{ }^{\prime} \quad 0 .
$$

By contrast, others have required ${ }^{4}$

$$
d \log \text { a } \& d \log L_{1} / L^{\prime} \quad 0 .
$$

Frequently however the latter approach can give rise to paradox since in the historical statistics it is often the case that $\left(d \log a-d \log L_{1} / L\right)$ and its converse $\left(d \log (1-a)-d \log L_{2} / L\right)$ have the same sign. The imbalance appears to have moved in the same direction for both skillgroups. That is why these studies so easily yield wild estimates of the effect of altered imbalances. Our definition ensures that, if the relative demand for the skilled increases relative to their supply, the opposite is true of the unskilled.

(ii) A neutral shift in wage pressure. Our definition allows wage pressure at given unemployment to grow at the same rate as the average wage would grow if there were no change in the composition of employment. ${ }^{5}$ Of course if the composition of the labour force is changing due to rising $\mathrm{L}_{1} / \mathrm{L}_{2}$ and this is reflected in $\mathrm{N}_{1} / \mathrm{N}_{2}$, with skillspecific unemployment rates constant, then the average wage paid will rise by more than $\mathrm{d} \log \mathrm{A}+\log \left(\mathrm{N}_{1} / \mathrm{N}_{2}\right) \mathrm{da}$ - due to a compositional effect. But if $d \log a /(1-a)=d \log \left(N_{1} / N_{2}\right)=d \log \left(L_{1} / L_{2}\right)$ then the wage within each skill group will rise by only $d \log A+\log \left(\mathrm{N}_{1} / \mathrm{N}_{2}\right)$ da. This seems the natural definition of a neutral change in skill-specific wage behaviour at given unemployment rates.

\section{Mismatch}

For some purposes we can usefully use a simpler decomposition than that provided in equation (5). When people ask: Is higher 
unemployment due to increased skills mismatch, they do not mean to include only the effect of $d \log B$. For suppose that wages have adjusted through an appropriate change in relative wage pressure - for example, an increase in B has been offset by an appropriate increase in $\mathrm{z}_{1}-\mathrm{z}_{2}$. Then there is no reason why aggregate unemployment should rise. Indeed that is just what happened in the US. So when people discuss mismatch they mean to include the full effects of the "imbalance shock" and the "relative wage shock" which may have offset it. This would leave an aggregate wage shock as the main alternative source of extra unemployment, since compositional effects are small.

This suggests the following short-cut approach to the mismatch issue, in which we do not identify separately the "imbalance shock" and the "relative wage shock". Instead we identify changes in "aggregate wage pressure" and label everything else a change in mismatch.

We first note that, from the demand functions,

$$
\text { a } \left.d \log W_{1} \% 1 \& a\right) d \log W_{2}{ }^{\prime} d \log A \% \operatorname{dog} \frac{N_{1}}{N_{2}} d a \text {. }
$$

We then substitute for $\mathrm{d} \log \mathrm{W}_{\mathrm{i}}$ by using the wage functions

$$
d \log W_{i}^{\prime} d z_{i} \& ? d \log u_{i}
$$

which gives

$$
d \bar{z} \& ?\left(\mathrm{a} d \log u_{1} \%(1 \& \mathrm{a}) d \log u_{2}\right)^{\prime} d \log A \% \operatorname{dog} \frac{N_{1}}{N_{2}} d \mathrm{a} .
$$

Dividing through by ? and then adding $\mathrm{d} \log \mathrm{u}$ to both sides gives 


$$
\begin{aligned}
& d u^{\prime} \frac{u}{?}\left(d \bar{z} \& d \log A \& \log \frac{N_{1}}{N_{2}} d \mathrm{a}\right) \%\left(\& \mathrm{a} d \log \frac{u_{1}}{u} \&(1 \& \mathrm{a}) d \log \frac{u_{2}}{u}\right) u \\
& \text { ' Aggregate wage pressure effect \% Mismatch effect. }
\end{aligned}
$$

The first term is the average excess rise in the wage function times $\mathrm{u} /$ ? (which reflects the degree of real wage resistence). The term is approximately equal to our previous measure of the effect of "aggregate wage pressure" in equation (5). ${ }^{6}$ The second term is therefore close to the sum of the other four terms in equation (5). It is a natural measure of mismatch and close to the measure of $1 / 2 \mathrm{~d} \operatorname{Var}\left(\mathrm{u}_{\mathrm{i}} / \mathrm{u}\right)$ advocated by Layard et al $(1991)^{7}$ and now widely used.

In the empirical section we show such measures of the change in mismatch in all the main European countries and in the US. We also show how these changes reflect the changes in employment and labour force within each skill group.

\section{EVIDENCE ON EUROPE AND THE US}

To examine the evidence, we split the labour force into two groups, skilled and the rest, where skilled includes everyone with the equivalent of English A levels or above (obtained around age 18). In Europe this is a fairly easy category to identify, while in the US we take as the equivalent "some college". ${ }^{8}$ In Annex 2 we give the basic time series for $\mathrm{L}_{1} / \mathrm{L}_{2}, \mathrm{~N}_{1} / \mathrm{N}_{2}$ and $\mathrm{W}_{1} / \mathrm{W}_{2}$ in each country.

\section{Production function}

The first step is to estimate the production function, pooling the time series for all countries. We assumed the production function to be CES, which gives a demand function. ${ }^{9}$ 


$$
\log \left(\frac{N_{1}}{N_{2}}\right)_{i t}{ }_{i t} \& s \log \left(\frac{W_{1}}{W_{2}}\right)_{i t} \%_{i} t \%_{i}{ }_{i}{ }_{i t}
$$

The estimated value of $\mathrm{s}$ was 1.024 (s.e. $=0.178$ ). ${ }^{10}$ This is support for the case of the Cobb-Douglas function. We calculate a throughout as the share of skilled labour in the total gross wage bill.

\section{Wage functions}

The next step is to estimate the wage functions. This is done for Britain (1975-92) and the US (1979-88) in Table 1. In each country the observations are average wages for each skill group in each region (10 regions in Britain, 9 in the US). The estimated equation is

$\log \mathrm{W}_{\text {stt }}=\mathrm{a}_{1} \mathrm{D}_{1} \mathrm{t}+\mathrm{a}_{2} \mathrm{D}_{2} \mathrm{t}-? \log \mathrm{u}_{\text {stt }}+\mathrm{bQ}_{\text {stt }}+$ fixed effects for $\mathrm{s}+$ fixed effects for $\mathrm{r}$

where $\mathrm{W}$ is the real gross wage (deflated by the GDP deflator), $s$ is skill, $r$ region, $t$ time, $\mathrm{D}_{1}$ and $\mathrm{D}_{2}$ dummies, and $\mathrm{Q}$ is a vector of quality variables including average experience, experience squared, and the proportions who are full-time, male, white, and in each 'industry'. Observations are weighted by the number of individuals in each cell.

The regression is done for average wages in each cell (rather than for each individual) partly because these cells are the units relevant to our theory and partly to avoid exaggerating the t-statistic on cellspecific unemployment. However the coefficient estimates obtained in regressions on individual data are very similar, provided cell-specific variables as well as individual variables are included as regressors.

As the analysis shows, time series movements in unemployment offset real wages with a similar coefficient ? in the US and Britain. However in Britain the time trends in the real wage intercept are very similar for the two skill groups, while in the US they are much lower for the unskilled. 
There is one further point stemming from the wage function. The quality $\left(Q_{s}\right)$ of each skill group is not static. If a group's quality improves, so does its labour supply. As Annex 2 explains, this requires a modification of equations (3) and (4) to adjust the labour supply for quality. But the coefficients a in the theory can continue to be measured exactly by the actual shares of the wage bill. ${ }^{11}$

\section{Changes in unemployment. Britain versus the US}

We can now proceed in Table 2 to explain the changes in unemployment over the sample period (UK 1975-92; US 1979-88). The theory we have developed relates essentially to the NAIRU and excludes nominal surprises. However, since within a country the years we have chosen are at similar points in the cycle, this is not a major problem.

As Table 2 shows, British unemployment grew over the period by 5.9 percentage points. To implement the explanatory framework set out in Annex Equations A1-3, we evaluate the coefficients by taking mean values of the variables that appear in each coefficient, evaluated over the whole period. One could of course perform the explanation separately for each year and then add up, but our simpler approximation works adequately. The evaluation is done separately for each region-and-skill group, and only then added up.

Overall, our model predicts that British unemployment grew by 5.5 points. The model also explains quite well the growth of skilled unemployment (by 3.5 points) and unskilled unemployment (by 7.5 points). The main explanatory factors are these.

(i) Imbalanced demand and supply shocks. In the labour market as a whole the relative demand for labour grew strongly. The relative supply of skill grew almost (but not quite) as fast. Thus over the period

$$
? \log \frac{\mathrm{a}}{1 \& \mathrm{a}} \& ? \log \frac{L_{1}}{L_{2}}, 12.4 \%
$$


This had the predicted effect of reducing skilled unemployment and raising unskilled. The net effect was an extra 0.7 points on overall unemployment - not a very large amount.

(ii) Relative wage shocks. Moreover some of the preceding effect was offset by relative wage restraint among the unskilled. Thus increased skill mismatch offers little explanation of the rise in British unemployment.

(iii) Aggregate wage pressure. By far the main explanation comes from increased wage pressure at a given unemployment rate - requiring unemployment to rise in order to offset it. This alone can explain the otherwise unexplained rise in unemployment among skilled workers.

Such wage pressure is of course a pure catch-all. For a proper understanding of why unemployment rose we have to look in detail at the impact of welfare systems, bargaining institutions, labour market regulations, tax systems and so on. ${ }^{12}$ These issues have been discussed at length elsewhere (Layard et al 1991). But, to isolate the impact of skills mismatch (as here), that is unnecessary.

(iv) The compositional effect. This is in a downward direction, due to the shift of the labour force into skill groups with lower unemployment rates. But it is a small part of the story.

Turning to the USA, there is little story to tell. The evolution of demand and supply was as imbalanced as in Britain. But almost all of this imbalance was offset by relative wage restraint in the unskilled labour market. The big difference from Britain was the absence of aggregate wage pressure. So aggregate unemployment barely changed.

Finally, while comparing Britain and the US, we can look at the simpler decomposition given by equation (6). This is shown in Table 3 and again attributes almost all the British increase in unemployment to increased aggregate wage pressure rather than to Krugman's imbalanced supply and demand shocks, and the response to them. The 
story is highly consistent with the more detailed analysis in Table 2 and thus provides us with some confidence in the short-cut approach.

\section{Increased mismatch? Europe versus the US}

It is therefore interesting to use this approach (which requires less data) to compare the USA with a wider range of European countries and over a large time span. As Table 4 shows, unemployment has risen substantially in most European countries except the Netherlands. But in most countries none of the increase can be attributed to increased mismatch, as measured in equation (6). Only in Italy, Britain and the US is there any explanation. This reflects trends in $\mathrm{u}_{2} / \mathrm{u}_{1}$ - see Figure 1.

Why has there been no increase in mismatch in Europe? It is due to the massive change in the supply of skilled people. Table 5 shows the annual change in relative demand and relative supply (unadjusted for "quality"). The story is quite remarkable. Both demand and supply have shifted hugely. In most countries the relative demand for skill has slightly outrun supply. But considering the size of the two changes, the difference between them is remarkably small, as Column (3) shows. The difference is particularly large in the US in the 1980s and also in Britain which is doubtless one of the reasons for the strong upwards pressure on skilled wages in the two countries.

The relative wage adjustment can be seen in Column (4). It was especially large in the US in the 1980s. In most European countries it was much less - but less wage adjustment was also needed, due to a better process of skill development.

Thus the evidence suggests fairly powerfully that rigid relative wages cannot be the main source of the rise in European unemployment. If they were the main reason, mismatch would have increased; that is $\mathrm{u}_{2} / \mathrm{u}_{1}$ would have risen. It did not.

A natural reaction to this analysis is to say that we have not used a fine enough division of skill. However we also used a three-fold breakdown of the labour force and applied it to a generalised version of our model in which we continued to measure asymmetric shocks by 
differences between $d \log a_{i} / a_{N}$ and $d \log L / L_{N}$ where $N$ was a numeraire group. The results were very similar to those in Table 2 .

A further objection is more subtle. It rests on the undoubted fact that in the US there has been an increase in wage dispersion within skills, reflecting a widening premium for other types of productive characteristics. Suppose now that there is in Europe some arbitrary cut-off to the permitted relative wage dispersion within each skill group. Then wage rigidities will increase the unemployment rates in each group and may increase them by the same proportion.

The first comment on this is that it does not seem reasonable to assume such a high binding wage floor in the skilled group. But, second, in most European countries there have in fact been very small increases within group inequality. ${ }^{13}$ This could of course be simply a symptom of total rigidity rather than just a wage floor. But, if that were it, there should be huge trend increases in reported shortages of desirable labour, for which there is little evidence. 


\section{CONCLUSIONS}

Thus we cast severe doubt on the widely-held view that unemployment rose in Europe, but not in America, due to less flexible skill differentials. The evidence in this paper says that the explanation lies elsewhere.

First we develop a framework which can decompose changes in skill-specific unemployment into changes due to (i) imbalanced demand and supply changes, (ii) shocks to the relative wage behaviour and (iii) changes in aggregate wage pressure. This shows that, both in the US and Europe, imbalanced demand and supply changes raised unskilled unemployment and reduced skilled unemployment. But some of this effect was offset by appropriate shifts in relative wage behaviour. Thus, taking (i) and (ii) together, changes in skill mismatch raised total unemployment in Britain since 1975 by under half a percentage point, and in the US by even less. The real difference between Britain and the US was the rise in aggregate wage pressure in Britain arising from the way in which the British economy was so vulnerable to the oil and productivity shocks. ${ }^{14}$ It is this alone which can explain the key fact about British and European unemployment that skilled unemployment has risen as much proportionally as unskilled. It is the total failure of the Krugman et al hypothesis to explain this fact which renders it so implausible.

Thus if one constructs a simple measure of changes in mismatch, corresponding roughly to the sum of items (i) and (ii) above, the only countries where this has risen are the US, Britain and Italy. In most of the other European countries studied, it has fallen. In the 1980s wage differentials have increased much less in Europe than in the US, but they needed to increase less because the rate of skill formation was so much higher in Europe.

While our analysis is quite limited, it surely calls in question the view that European unemployment rose because of increased relative demand for skill, interacting with rigid relative wages. There was simply not the fall in unemployment of skilled workers which the 
theory predicts. ${ }^{15}$ Instead we have to look above all at explanations based on the European welfare state and its effect on all groups of labour. 


\section{ENDNOTES}

1. For other discussions of US and European wage dispersion and its correlates see Freeman and Katz (1994) and the collection of papers in Freeman and Katz (1995). See also Juhn et al (1993).

2. Note that $(1 \& \mathrm{a}) d \log \frac{\mathrm{a}}{1 \& \mathrm{a}}{ }^{\prime}(1 \& \mathrm{a})\left(\frac{1}{\mathrm{a}} \% \frac{1}{1 \& \mathrm{a}}\right) d \mathrm{a}^{\prime} d \log \mathrm{a}$.

3. This form is well-supported by much evidence, especially in Europe - see for example Layard et al (1991) and Blanchflower and Oswald (1994).

4. Nickell and Bell (1995), Manning et al. (1996).

5. In this case $\frac{d W_{1}}{W} \frac{1}{W}\left(\frac{N_{1}}{N} d W_{1} \% \frac{N_{2}}{N} d W_{2}\right)$

$$
\text { ' } \left.\operatorname{ad} \log W_{1} \% 1 \& a\right) d \log W_{2}
$$

Furthermore from the two labour demand functions we know that (whatever happens to $\mathrm{N}_{1} / \mathrm{N}_{2}$ ),

$$
\text { a } \left.d \log W_{1} \% 1 \& \mathrm{a}\right) d \log W_{2}^{\prime} d \log A \% \operatorname{dog} \frac{N_{1}}{N_{2}} d a \text {. }
$$

6. If $\mathrm{u}_{1}=\mathrm{u}_{2}$ the two measures are identical (see Annex 1). But when $\mathrm{u}_{1} O \mathrm{O}_{2}$, the coefficient in equation (5) is less than $\mathrm{u} /$ ? because the aggregate wage shock leads to a fall in the dispersion of the relative unemployment rates (see also Nickell and Bell, 1995). The difference however is not large if say $\mathrm{u}_{1}=1 / 2 \mathrm{u}_{2}$.

7. The measure in Layard et al (1991) is -ud (a $\log \mathrm{u}_{1} / \mathrm{u}+(1-\mathrm{a}) \log$ $\left.\mathrm{u}_{2} / \mathrm{u}\right)$. The present measure is more logical. The previous 
measure equals the present measure plus $\left(-\log \mathrm{u}_{2} / \mathrm{u}_{1}\right.$ da). This may be positive or negative but in our sample of countries is negative (with da $>0$ and $\mathrm{u}_{2}>\mathrm{u}_{1}$ ).

8. We do the same for Spain since the available classification provides no clearer breakpoint.

9. This corresponds to the production function

$$
\begin{gathered}
Y^{\prime} A\left(a_{1} N_{1}^{?} \% a_{2} N_{2}^{?}\right)^{\frac{1}{?}}, \text { with } \\
\left(\frac{a_{1}}{a_{2}}\right)^{\mathrm{s}}{ }^{\prime} e^{B t} \text {.const. }
\end{gathered}
$$

10. For separate regressions done for Britain and the US using lagged $\mathrm{W}_{1} / \mathrm{W}_{2}$ as an instrument, the estimates of s were 1.13 (s.e. $=0.19$ ) and 1.74 (s.e. $=0.64$ respectively).

11. $\mathrm{d} \log \mathrm{A}$ is calculated as $\mathrm{d} \log \mathrm{A}=\mathrm{d} \log \mathrm{WN}-\mathrm{d}\left(\mathrm{a}_{1} \log \mathrm{N}_{1} \mathrm{X}_{1}\right)-\mathrm{d}\left(\mathrm{a}_{2}\right.$ $\log \mathrm{N}_{2} \mathrm{X}_{2}$ ) where $\mathrm{X}_{\mathrm{i}}$ is defined in Annex 3.

12. The best explanation of rising European unemployment is in terms of an economic system that worked alright if not shocked, but was fragile in the face of shocks - leading to the emergence of behaviour unfriendly to employment. Thus across countries we have ? $\mathrm{u}$ related to the level of institutional variables.

13. See OECD, Employment Outlook, 1993, p.162.

14. In addition incomes policy which had helped to contain wage pressure from 1975-9 was abandoned in 1979.

15. This does not mean that the level of mismatch is not an important issue in both Europe and America, see Layard et al (1991, Chapter 6, p.310). 


\section{ANNEX 1}

\section{Deriving equation (5)}

We first solve for $\mathrm{du}_{1}$ and $\mathrm{du}_{2}$, using equations ( $\left.3^{\prime}\right)$ and (4'). This gives

$$
\begin{aligned}
& d u_{1}{ }^{\prime} M\left\{\frac{?(1 \& \mathrm{a})}{u_{2}} d \log B\right. \\
& \% \frac{\mathrm{a} u_{2} \%\left(1 \& u_{2}\right)}{u_{2}\left(1 \& u_{2}\right)}\left(d z_{1} \& d \bar{z}\right) \% \frac{1 \& \mathrm{a}}{1 \& u_{2}}\left(d z_{2} \& d \bar{z}\right) \\
& \left.\% \frac{\mathrm{a} u_{2} \%\left(1 \& u_{2}\right) \%(1 \& \mathrm{a}) u_{2}}{u_{2}\left(1 \& u_{2}\right)} d A W P\right\}
\end{aligned}
$$

where $M^{\prime} \frac{u_{1} u_{2}\left(1 \& u_{1}\right)\left(1 \& u_{2}\right)}{?\left(?\left(1 \& u_{1}\right)\left(1 \& u_{2}\right) \% u_{2} \%(1 \& a) u_{1} \& u_{1} u_{2}\right)}>0$

Similarly,

$$
\begin{aligned}
& d u_{2}^{\prime} M\left\{\& \frac{? \mathrm{a}}{u_{1}} d \log B\right. \\
& \% \frac{\mathrm{a}}{1 \& u_{1}}\left(d z_{1} \& d \bar{z}\right) \% \frac{(1 \& \mathrm{a}) u_{1} \%\left(1 \& u_{1}\right)}{u_{1}\left(1 \& u_{1}\right)}\left(d z_{2} \& d \bar{z}\right) \\
& \left.\% \frac{(1 \& \mathrm{a}) u_{1} \%\left(1 \& u_{1}\right) \% u_{1}}{u_{1}\left(1 \& u_{1}\right)} d A W P\right\}
\end{aligned}
$$


Aggregate unemployment is given by $u^{\prime} u_{1} \frac{L_{1}}{L} \% u_{2} \frac{L_{2}}{L}$ The change in unemployment is therefore

$$
\begin{aligned}
& d u^{\prime} \mathrm{R} d u_{1} \% 1 \& \mathrm{R} d u_{2} \%\left(u_{1} \& u_{2}\right) d \mathrm{R}, \text { with } \mathrm{R} \frac{L_{1}}{L} \text {, or } \\
& d u^{\prime} M\left\{\left(\mathrm{R}^{\left.\mathrm{a} u_{2} \%\left(1 \& u_{2}\right) \% 1 \& \mathrm{a}\right) u_{2}}\right.\right. \\
& \% ?\left\{\left(1 \& \mathrm{~B} \frac{\mathrm{a}}{u_{1}} \& \mathrm{R} \frac{1 \& \mathrm{a}}{u_{2}}\right) d \log B\right\} \\
& \%\left(\mathrm{R} \frac{\mathrm{a} u_{2} \%\left(1 \& u_{2}\right)}{u_{2}\left(1 \& u_{2}\right)} \% 1 \& \mathrm{~B} \frac{\mathrm{a}}{1 \& u_{1}}\right)\left(d z_{1} \& d \bar{z}\right) \\
& \%\left(1 \& \mathrm{~B} \frac{(1 \& \mathrm{a}) u_{1} \%\left(1 \& u_{1}\right)}{u_{1}\left(1 \& u_{1}\right)} \% \frac{1 \& \mathrm{a}}{1 \& u_{2}}\right)\left(d z_{2} \& d \bar{z}\right) \\
& \left.\% 1 \& \mathrm{~B} \frac{(1 \& \mathrm{a}) u_{1} \%\left(1 \& u_{1}\right) \% u_{1}}{u_{1}\left(1 \& u_{1}\right)}\right) d A W P \\
& \%\left(u_{1} \& u_{2}\right) d \mathrm{R}
\end{aligned}
$$

Note that, in the case where $u_{1}{ }^{\prime} u_{2}{ }^{\prime} u$, the coefficient on d AWP is 


$$
\begin{aligned}
& \left.\frac{u^{2}(1 \& u)^{2}}{?\left(?(1 \& u)^{2} \% u \& u^{2}\right)}\left(l \frac{\mathrm{a} u \% ?(1 \& u) \%(1 \& \mathrm{a}) u}{u(1 \& u)} \% 1 \& l\right) \frac{(1 \& \mathrm{a}) u \% ?(1 \& u) \% u}{u(1 \& u)}\right) \\
& \text { ' } \frac{u^{2}(1 \& u)^{2}}{?\left(?(1 \& u)^{2} \% u \& u^{2}\right)} \frac{u \% ?(1 \& u)}{u(1 \& u)} \\
& \text { ' } \frac{u(1 \& u)(u \% ?(1 \& u))}{?(1 \& u)(u \% ?(1 \& u))} \cdot \frac{u}{?}
\end{aligned}
$$


ANNEX 2

Basic data 


\section{United States}

Sources: Available on request. 


\section{ANNEX 3}

\section{Adjustment for "quality"}

To make a satisfactory analysis of the race between demand and supply, we have to control for the fact that workers vary in "quality" not only according to skill but also experience, experience ${ }^{2}$, fulltime/part-time, sex and race. Call this vector $\mathrm{Q}$, which affects the wage of skill groups according to

$\log W_{s}{ }^{\prime} a_{s} t \& ? \log u_{s} \% \boldsymbol{\phi} Q_{s} \%$ egional dummies.

where $\mathrm{W}_{\mathrm{s}}$ is the average real wage per person.

We can for convenience designate $b_{\mathrm{s}}$ by the expression $\log \mathrm{X}_{\mathrm{s}}$. It follows that the wage equation for skill group 1 has to be re-written as

$$
\log W_{1} \& \log X_{1}^{\prime} \quad z_{1}(t) \& ? \log u_{1}
$$

The demand function for persons in skill group 1 also has to be rewritten to allow for quality. Suppose the true production function is

$$
Y^{\prime} A\left(N_{1} X_{1}\right)^{\mathrm{a}}\left(N_{2} X_{2}\right)^{1 \& a}
$$

where $\mathrm{N}_{1} \mathrm{X}_{1}$ is measured in efficiency units. The demand for an efficiency unit of skill group 1 is then 
$\log W_{1} \& \log X_{1}{ }^{\prime} \log A \% \operatorname{dog} a \&(1 \& a) \log \frac{N_{1} X_{1}}{N_{2} X_{2}}$

$$
\begin{aligned}
& ' \log A \% \log a \&(1 \& a) \log \frac{N_{1} X_{1}}{L_{1} X_{1}} \%(1 \& a) \log \frac{N_{2} X_{2}}{L_{2} X_{2}} \&(1 \& a) \log \frac{L_{1} X_{1}}{L_{2} X_{2}} \\
& \left.' \log A \% \log a \&(1 \& a) \log \left(1 \& u_{1}\right) \% 1 \& a\right) \log \left(1 \& u_{2}\right) \&(1 \& a) \log \frac{L_{1} X_{1}}{L_{2} X_{2}}
\end{aligned}
$$

Combining (A.1) and (A.2) gives a new version of equation (3) in which changes in labour supply have to be modified to allow for changes in quality - and the ratio $\mathrm{N}_{1} / \mathrm{N}_{2}$ must also be modified. The new equation is

$$
\begin{aligned}
& d u_{1}{ }^{\prime} \mathrm{f}_{1}(1 \& \mathrm{a})\left(d \log \frac{L_{1} X_{1}}{L_{2} X_{2}} \& d \log \frac{\mathrm{a}}{1 \& \mathrm{a}}\right) \\
& \%_{1}\left(d z_{1} \& d \log A \& \log \frac{N_{1} X_{1}}{N_{2} X_{2}} d \mathrm{a}\right) \%{ }_{1}(1 \& \mathrm{a}) \frac{d u_{2}}{1 \& u_{2}}
\end{aligned}
$$

We make these modifications to $d \log \frac{L_{1}}{L_{2}}$ and $\log \frac{N_{1}}{N_{2}}$ wherever we "allow for quality". 


\section{TABLE 1}

\section{Wage equation}

Dependent variable: log of average real region-skill-specific wage

\begin{tabular}{|c|c|c|c|c|}
\hline & \multicolumn{2}{|c|}{ Britain } & \multicolumn{2}{|c|}{ US } \\
\hline $\log u_{\text {srt }}$ & -.0302 & (4.4) & -.0363 & (2.3) \\
\hline$D_{1} t$ & 0195 & (13.3) & -.0054 & (1.5) \\
\hline$D_{2} t$ & .0191 & $(15.5)$ & -.0120 & (4.4) \\
\hline $\begin{array}{l}\mathrm{D}_{2} \\
\text { (unskilled) }\end{array}$ & -.4346 & (10.5) & -.3048 & (4.2) \\
\hline $\begin{array}{l}\text { Average } \\
\text { experience }\end{array}$ & .0336 & (3.1) & 0513 & (2.5) \\
\hline $\begin{array}{l}\text { (Average } \\
\text { experience) }\end{array}$ & -.0004 & (1.9) & -.0014 & $(2.7)$ \\
\hline $\begin{array}{l}\text { Proportion } \\
\text { full-time }\end{array}$ & .7148 & (6.4) & .8846 & $(2.8)$ \\
\hline $\begin{array}{l}\text { Proportion } \\
\text { male }\end{array}$ & 2640 & (2.1) & .0823 & (.4) \\
\hline $\begin{array}{l}\text { Other } \\
\text { variables }\end{array}$ & $\begin{array}{l}\text { Race } \\
\% \text { in each ind } \\
\text { Regional dum }\end{array}$ & & $\begin{array}{l}\text { Race } \\
\% \text { in each ind } \\
\text { Regional dum }\end{array}$ & \\
\hline $\begin{array}{l}\mathrm{N} \\
\mathrm{Q}^{2}\end{array}$ & $\begin{array}{l}357 \\
.976\end{array}$ & & $\begin{array}{l}162 \\
.980\end{array}$ & \\
\hline Dates & $1975-92$ & & $1979-83,1985$ & \\
\hline
\end{tabular}

Source of data: UK General Household Survey. Approx 10,000 individuals per year.

US CPS March outgoing rotation groups. 20\% random sample within each gender-education cell. Result: 30,000 individuals per year? 
TABLE 2A

Decomposing the change in unemployment rates (percentage points) Britain 1975-92

\begin{tabular}{|l|r|r|r|}
\hline & Skilled & Unskilled & \multicolumn{2}{|c|}{ Total } \\
\hline $\begin{array}{l}\text { Imbalanced } \\
\text { D+S shocks } \\
\begin{array}{l}\text { Relative wage } \\
\text { shocks }\end{array}\end{array} \quad-1.05$ & 1.28 & 0.71 \\
$\begin{array}{l}\text { Aggregate wage } \\
\text { shock }\end{array}$ & 0.05 & -0.34 & -0.27 \\
$\begin{array}{l}\text { Compositional } \\
\text { change }\end{array}$ & 5.02 & 6.29 & 5.98 \\
Total explained & 0.05 & -0.12 & -0.97 \\
\hline Actual & 3.96 & 7.11 & 5.46 \\
\hline
\end{tabular}

TABLE 2B

Decomposing the change in unemployment rates (percentage points)

USA 1979-88

\begin{tabular}{|l|r|r|r|}
\hline & \multicolumn{1}{|c|}{ Skilled } & Unskilled & \multicolumn{1}{c|}{ Total } \\
\hline $\begin{array}{l}\text { Imbalanced } \\
\text { D+S shocks }\end{array}$ & -0.60 & 1.65 & 0.66 \\
$\begin{array}{l}\text { Relative wage } \\
\text { shocks }\end{array}$ & 0.50 & -1.36 & -0.54 \\
$\begin{array}{l}\text { Aggregate wage } \\
\text { shock }\end{array}$ & -0.11 & -0.15 & -0.14 \\
$\begin{array}{l}\text { Compositional } \\
\text { change }\end{array}$ & -0.05 & -0.10 & -0.33 \\
Total explained & -0.27 & 0.04 & -0.36 \\
\hline Actual & -0.07 & 0.27 & -0.05 \\
\hline
\end{tabular}

Note: The compositional change includes shifts in the composition of workers between regions as well as between skill groups. 


\section{TABLE 3}

Decomposing the change in aggregate unemployment: simplified approach (percentage points)

\begin{tabular}{|c|c|c|}
\hline & Britain (1975-92) & US (1979-88) \\
\hline Mismatch shock & 0.14 & 0.05 \\
Aggregate wage shock & 6.87 & -0.16 \\
\cline { 2 - 3 } Total explained & 7.01 & -0.11 \\
\hline Actual & 5.90 & -0.05 \\
\hline
\end{tabular}

Note: Both the first two rows are independently calculated, using (6).

TABLE 4

Change in aggregate unemployment: simplified approach (percentage points)

\begin{tabular}{|l|c|r|r|}
\hline Country & Period & $\begin{array}{c}\text { Change due to } \\
\text { mismatch }\end{array}$ & Total change \\
\hline USA. & $70-91$ & - & 1.4 \\
Britain & $75-92$ & .01 & 5.9 \\
France & $78-94$ & - & 7.3 \\
Italy & $77-93$ & - & 3.3 \\
Netherlands & $75-93$ & -0.2 & 2.3 \\
Norway & $72-93$ & -0.3 & 4.0 \\
Sweden & $71-93$ & -0.1 & 5.8 \\
& & & \\
Australia & $79-93$ & -0.1 & 5.0 \\
Canada & $75-93$ & -0.1 & 4.3 \\
\hline
\end{tabular}




\section{TABLE 5}

Annual change in relative demand and relative supply

All variables have been multiplied by 100

\begin{tabular}{|l|c|cccccc|}
\hline & Years & $\begin{array}{c}\mathrm{d} \log \\
(\mathrm{a} /(1-\mathrm{a})) \\
(1)\end{array}$ & $\begin{array}{c}\mathrm{dlog} \\
\left(\mathrm{L}_{1} / \mathrm{L}_{2}\right)\end{array}$ & $\begin{array}{c}(1)-(2) \\
(3)\end{array}$ & $\begin{array}{c}\mathrm{dlog} \\
\left(\mathrm{W}_{1} / \mathrm{W}_{2}\right) \\
(4)\end{array}$ & $\begin{array}{c}\mathrm{d} \log \\
\left(\mathrm{N}_{1} / \mathrm{N}_{2}\right) \\
(5)\end{array}$ & $\begin{array}{c}(5)-(2) \\
(6)\end{array}$ \\
\hline USA & $70-89$ & 5.24 & 4.59 & 0.65 & 0.50 & 4.74 & 0.15 \\
& $70-79$ & 5.67 & 6.77 & -0.90 & -1.26 & 6.93 & 0.26 \\
& $80-89$ & 4.60 & 3.21 & 1.39 & 1.35 & 3.25 & 0.04 \\
Britain & $74-92$ & 7.55 & 6.82 & 0.73 & 0.52 & 7.03 & 0.21 \\
France & $84-93$ & 6.51 & 6.09 & 0.42 & 0.22 & 6.29 & 0.20 \\
Italy & $77-92$ & 6.52 & 6.27 & 0.25 & -0.14 & 6.66 & 0.29 \\
Nether- & & & & & & & \\
lands & $85-90$ & 5.34 & 5.92 & -0.58 & -0.15 & 5.49 & -0.43 \\
Norway & $79-93$ & 6.25 & 6.16 & 0.09 & -0.15 & 6.40 & -0.14 \\
Spain & $77-93$ & & 5.05 & & & 5.58 & 0.53 \\
Sweden & $71-93$ & 7.17 & 6.84 & 0.33 & 0.32 & 6.85 & 0.01 \\
& & & & & & & \\
Australia & $79-90$ & 5.49 & 5.01 & 0.48 & 0.39 & 5.10 & 0.09 \\
Canada & $79-93$ & 5.85 & 5.49 & 0.36 & 0.39 & 5.46 & -0.03 \\
\hline
\end{tabular}

Note: Column (6) is approximately equal to $100\left(\mathrm{du}_{2}-\mathrm{du}_{1}\right)$. 


\section{FIGURE 1}

Relative unemployment rates (unskilled/skilled, i.e. $\mathbf{u}_{2} / \mathbf{u}_{1}$ )



\section{REFERENCES}

Blanchflower, D. and Oswald, A. (1994), The Wage Curve, MIT Press, Cambridge.

Freeman, R. and Katz, L. (1994), 'Rising Wage Inequality: The United States vs Other Advanced Countries', in Freeman, R. (ed) Working under Different Rules, New York, Russell Sage Foundation.

Freeman, R. and Katz, L. (1995), Differences and Changes in Wage Structures, Chicago, The University of Chicago Press.

Juhn, C., Murphy, K. and Pierce, B. (1993), 'Wage Inequality and the Rise in the Returns to Skills', Journal of Political Economy, 101(3), 410-442.

Krugman, P. (1994), 'Past and Prospective Causes of High Unemployment', in Reducing Unemployment: Current Issues and Policy Options, Jackson Hole Conference, WY.

Layard, R., Nickell, S. and Jackman, R. (1991), Unemployment, Macroeconomic Performance and the Labour Market, Oxford, Oxford University Press.

Manning, A., Wadsworth, J. and Wilkinson, D. (1996), 'Making Your Mind Up: Skill Mismatch in the UK', LSE mimeo.

Nickell, S. and Bell, B. (1995), 'The Collapse in the Demand for Unskilled and Unemployment Across the OECD', Oxford Review of Economic Policy, 11(1), pp. 40-62. 